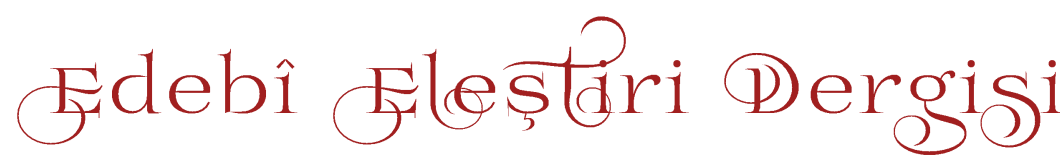

\author{
(Journal of Literary Criticism) \\ ISSN: 2602-46I6 \\ Cilt II, Sayı I, Nisan 2018
}

YÜKLENME TARIHI: 19.03.20I8 KABUL TARIHI: 23.04.20I8 YAYIN TARİHI: 30.04.2018

\author{
Ayşen ÇAĞLAYAN \\ Sakarya Üniversitesi Sosyal Bilimler \\ Enstitüsü Türk Dili ve Edebiyat1 \\ Anabilim Dalı Yüksek Lisans \\ Öğrencisi \\ aysencaglayan45@gmail.com \\ ORCID: 0000-0001-9383-7333
}

\section{ADALET AĞAOĞLU'NUN FİKRİMİN İNCE GÜLÜ ROMANININ \\ YOLCULUK/AŞAMA \\ ARKETİPİ BAĞLAMINDA ÇÖZÜMLENMESİ}

\author{
AN ANALYSIS OF \\ ADALET AĞAOĞLU'S \\ FİKRIMIN İNCEGÜLÜ \\ NOVEL IN THE \\ CONTEXT OF \\ TRAVEL/STAGE \\ ARCHETYPE
}

\section{ÖZ}

Destan döneminden başlayarak anlatılar; tanrılar, yarı tanrılar, yüce varlıklar ya da üstün insanların maceralarını konu edinmiștir. Suradan olmayan bu kahramanların daha doğumlarından itibaren diğerlerinden farklı oldukları, bir amacı gerçekleştirmek üzere dünyaya geldikleri belli edilir. Bu hedefi gerçekleştirmek üzere yola çıkarlar ve kimi zaman olağanüstü özellikler taşıyan yardımcıların da desteğiyle güçlükleri aşarak önceden belirli kaderlerini gerçekleştirirler. Ayrıldıkları topraklara, sembolik bir yeniden doğuşla yeni kimlik ve kişiliklerini kazanmış olarak dönerler. Daha sonraları bu anlayıș değișmiș, özellikle 20 . yüzyıldan itibaren sıradan insanlar edebi metinlerin kahramanları arasına girmiştir. 20. yüzyıl sonlarında postmodernist anlayışın da etkisiyle klasik kahraman anlayışında bütünüyle bir değişiklik yaşanmış ve anti-kahramanlar ortaya çıkmıştır. Geleneksel metinlerin idealize edilmiş üstün kahramanlarının da modernpostmodern metinlerin anti-kahramanlarının da maceraları aslında bir yolculuk hikâyesidir. Joseph Campbell'in "ayrılma, erginlenme ve dönüş" olarak ifade ettiği bu yolculuk sonunda kahraman büyük bir değișim geçirir. Kahramanlardan farklı
Beginning from the period of sagas, the narratives include the adventures of gods, demigods, sacred creatures or superhumans. It is made clear that, these extraordinary heroes are different since their birth and they come into the world to fulfill a specific goal. To achieve that goal, they depart and sometimes with the help of supernatural proponents, overcome with the challenges they encounter and fulfill their preordained destiny. They return to the lands they have left with a symbolic rebirth, a new identity and a new character. Later on, this concept has altered by the time and especially by the $20^{\text {th }}$ century, ordinary people started to participate in the protagonists of the literary works. At the end of the $20^{\text {th }}$ century, with the effect of the postmodernism trend, the ordinary hero perception has totally changed, and antiheroes showed up. Both the adventures of the idealized heroes of traditional works and the antiheroes of the adventures of modern/postmodern works are in fact a travel story. At the end of this story, which Joseph Campbell describes as "seperation- progress and return", the hero experiences a great alteration. In contradiction to the hero, antihero's destiny advances not to the achievement but to failure. The protagonist of Adalet Ağaoğlu's 
olarak anti-kahramanların yazgısı kazanmaya değil kaybetmeye doğru ilerler. Adalet Ağaoğlu'nun Fikrimin İnce Gülü adlı romanının başkişisi Bayram da bu aşamaları yaşamış bir anti-kahraman olarak karşımıza çıkar. Anahtar Kelimeler: Adalet Ağaoğlu, Fikrimin İnce Gülü, antikahraman, yolculuk/aşama arketipi.
Fikrimin İnce Gülü novel, Bayram, is an antihero who lived through all of these periods above. Keywords: Adalet Ağaoğlu, Fikrimin İnce Gülü, anti-hero, travel/stage archetype.

\section{GİRIŞ}

13 Ekim 1929 Ankara doğumlu Adalet Ağaoğlu gerek ele aldığ konular gerekse kullandığı yeni anlatım biçimleriyle özellikle 1970 sonrasında adından çokça söz ettirmiştir. İlk romanı Ölmeye Yatmak 1973 yılında yayımlansa da yazma denemelerine lise yıllarında başlar. Feridun Andaç'la yaptığı uzun söyleşide lisedeyken her gece bir roman yazdığını, ertesi gün bunları onu heyecanla bekleyen birkaç arkadaşına okuduğunu anlatır. Ağaoğlu'nun 1942-1946 yıllarına denk gelen lise öğrenimi İkinci Dünya Savaşı'nın da yaşandığı yıllardır. Türkiye savaşa doğrudan katılmamış olsa da birtakım güvenlik tedbirleri alınır. Muhtemel hava saldırılarına karşı geceleri şehri aydınlatan bütün 1şıkların kapatılması şeklinde uygulanan karartmalar da bunlardan biridir. Hem karartmalar hem ailesinin verdiği tepkiler nedeniyle Ağaoğlu yazılarını herkes uyuduktan sonra gaz lambası 1şı̆̆ında gizli gizli yazmaya başlar. ${ }^{1} \mathrm{Bu}$ acemilik döneminden geriye sadece iki eser kalmıştır. Bunlardan birisi lisedeki arkadaşlarından birinin yıllarca sakladıktan sonra Ağaoğlu'na verdiği bir defterde bulunan yazıları, diğeri de fakültedeyken yazmaya başlayıp yarım bıraktığı bir romandır. ${ }^{2}$ Ağaoğlu, bir gençlik hevesi olarak şiir yazmayı da denemiştir. $\mathrm{Bu}$ şiirler 1948-1949 yıllarında Kaynak dergisinde yayımlanmıştır. Ağaoğlu'na göre bunlar berbat şiirlerdir. ${ }^{3}$

Ağaoğlu, tiyatro türüyle de yoğun olarak ilgilenmiştir. İlk oyunu Sevim Uzgören ile birlikte yazdığı Bir Piyes Yazalım adlı oyundur. Devlet Tiyatrosu'nda sahneletmeyi başardıkları bu oyuna özellikle erkek eleştirmenlerden gelen kişiliğe saldıracak derecedeki tepkiler ${ }^{4}$ onu bir süre yazmaktan alıkoyar. Ancak daha sonra Yaşamak, Evcilik Oyunu, Tombala, Çatıdaki Çatlak, Kendini Yazan Şarkı gibi oyunlarla yazarlık serüvenine devam eder. 1960-1970 yılları arasında oyun yazarlı̆̆ı, çalışmalarının ana

\footnotetext{
${ }^{1}$ Kamuran Eronat, (2010). Adalet Ağaoğlu, Insan ve Eser, Ankara: Maya Akademi Yayınları, s. 7.

${ }^{2}$ Feridun Andaç, (2000). Adalet Ă̆aoğlu Kitabl/Sen Türkiye'nin En Güzel Kazasısın,

İstanbul: Türkiye İş Bankası Kültür Yayınları, s. 38-39.

${ }^{3}$ Feridun Andaç, age, s.38.

${ }^{4}$ Feridun Andaç, age, s. 47 .
} 
noktası olmuştur. Ağaoğlu, Ankara'nın ilk özel tiyatrosu Meydan Sahnesi'nin de kurucuları arasındadir. ${ }^{5}$

Sürekli bir ifade arayışı içerisinde olan yazar, kendi deyimiyle oyun yazarlığının yetmezliği nedeniyle romana yönelir. ${ }^{6}$ Tiyatro ne yazarın Cumhuriyet analizi yapma hedefini gerçekleştirebilecek ne de "zaman"la istediği gibi oynamasını sağlayacak nitelikte bir türdür.

Ağaoğlu'nun romanlarında toplumun gelişim ve değişim süreçleri bireyin değişim ve gelişim süreci üzerinden verilir. Her romanında toplumu sarsan bir olayın hazırladığ 1 zemin açıkça görülebilir. İlk romanı Ölmeye Yatmak'ta bir otel odasında ölmeye yatan Doçent Aysel ve onu intihar kararına götüren süreç anlatılırken Atatürk sonrası Türkiye'yi, İşçi Partisi mitinglerini, Demokrat Parti'nin oluşum sürecini, Amerika'yla giderek artan ilişkileri görmek mümkündür. Bir Dügün Gecesi ’nde 1970'li y1llardaki genel tablo özellikle de 12 Mart sürecinde yaşananlar, Hayır'da 12 Eylül sonrası, $\ddot{U}_{C ̧}$ Beş Kişi'de 12 Eylül öncesi anarşi dönemi takip edilebilir. Fikrimin İnce Gülü romanında da Türk toplumsal hayatında önemli etkileri olan Almanya'ya işçi göçü ele alınır.

İkinci Dünya Savaşı sonrasında bazı gelişmiş Avrupa ülkeleri, nüfus artışları işgücü ihtiyaçlarını karşılamayınca az gelişmiş ülkelerdeki nüfustan faydalanma yoluna gider. 1950'li yılların sonunda bireysel olarak başlayan işçi göçü, 1961'de Federal Almanya ile yapılan "İşgücü Göçü Antlaşması" ile devlet tarafindan desteklenir. İstanbul, özellikle de Tophane ve Mecidiyeköy bir işçi pazarı hâline gelir. Başlangıçta ailelerin dağılmasına bir önlem olarak işçilerin iki yıl sonra dönmeleri, yerlerine başka işçilerin gönderilmesi planlanır. Ancak Alman işvereni yetiştirilmiş işçisini bırakmak istemez ve 1963 'te antlaşmanın bu maddesi tek taraflı olarak kaldırılır, işçilere ailelerini yanlarına getirme hakk1 verilir. ${ }^{7}$

Almaya'ya aile göçüyle birlikte Türk nüfusu artar ve Türk mahalleleri oluşmaya başlar. Almanya'da başlayan yeni yaşam tarzı hem gidenler hem de geride kalanlar için yeni sorunları beraberinde getirir. Bir göçmen ülkesi olmak istemeyen Almanya, bu işçileri önce "Gastarbeiter" (misafir işçi) olarak adlandırmış, dönüşler gecikince "Mitarbeiter" (Çalışma arkadaşı) demeyebaşlanmış, kalıcı oldukları kesinleştiğinde ise "Migranten " (Göçmenler) terimini kullanmıştır. Bu tür işgücü tanımlamalarının yanında

\footnotetext{
${ }^{5}$ Seyit Battal Uğurlu, (2010). Adalet Ağaoğlu'nun Hayatı, Roman ve Hikayeleri Üzerine bir Araştırma, Ankara: Milli eğitim Bakanlığı Yayınları, s.68.

${ }^{6}$ Feridun Andaç, ( 2000 ). Adalet A ğaoğlu Kitabl/Sen Türkiye'nin En Güzel Kazasisın, İstanbul: Türkiye İș Bankası Kültür Yayınları, s.63.

${ }^{7}$ Mehmet Narlı, (2009). Roman Ne Anlatır, Ankara Akçağ Yayınları, s. 154.
} 
bu işçiler alışılmadık davranışlarında ötürü Türkiye'de "Almancı", her halleriyle yaşadıkları toplumdan farklı olduklarını belli ettikleri için Almanya'da "auslander" (yabancı) olarak adlandırılmıştır. ${ }^{8}$ İki ülke ve iki kültür arasında bocalamaya başlayan bu insanların yaşadıkları yazarları da kısa sürede harekete geçirir ve Almanya'ya göç, bir kısmı göç tecrübesini yaşayan Bekir Yıldız, Necati Tosuner, Gülten Dayığlu, Aras Ören, Demir Özlü, Tarık Dursun K. gibi isimler tarafından işlenir.

İlk baskısı 1976 yılında yapılan Fikrimin İnce Gülü, ilk üç baskıda herhangi bir sorun yaşanmamasına rağmen 1981'de dördüncü baskısı satışa çıkmak üzereyken devletin askeri kuvvetlerini yayın yoluyla tahkir ve tezyif ettiği gerekçesiyle yasaklı romanlar arasına alınmış, yazarı hakkında da1-6 yıl hapis isteğiyle dava açılmıştır. ${ }^{9}$ Kısa süre sonra yazar da roman da aklanır. 1993 yılında roman "Sarı Mercedes" adıyla Tunç Okan tarafından sinemaya uyarlanır. ${ }^{10}$

Bir yolculuk hikâyesi olan Fikrimin İnce Gülü, araştırmacılar tarafindan daha çok insan-nesne ilişkisi ve dış göç olgusu açısından incelenmiştir. Bu çalışmada Adalet Ağaoğlu'nun bir araba almak amaciyla Almanya'ya çalışmaya giden Bayram'ın hikayesini Bayram'ın iç çatışmalarıyla anlattı̆g Fikrimin Ince Gülü romanı Joseph Campbell'in "ayrılma, erginlenme ve dönüş" şeklinde formüle ettiği yolculuk/aşama arketipi bağlamında incelenecektir. Romanda olaylar geriye dönüşlerle anlatılır. "Ayrılma, erginlenme ve dönüş" aşamalarının sağlıklı bir şekilde verilebilmesi amacıyla olaylar mümkün olduğu kadar kronolojik bir sıraya konularak ele alınacaktır.

\section{Anti-kahraman Kimdir/Nedir?}

Açıklaması güç olan "anti-kahraman" teriminin edebiyat eleştirisinde kullanımı oldukça yenidir. Ancak anti-kahraman özelliğine sahip kahramanlar, edebî eserlerde varlıklarını daha eski dönemlerde göstermeye başlamıştır. "Anti-kahraman" terimi sözlüklerde farklı tanımlarla verilmiştir. "kahramanca niteliklerde göze çarpmayan bir başkişi ya da önemli bir figür" ${ }^{11}$, "zihin ve ruh soyluluğu, aksiyon ya da amaçla işaretlenmiş bir hayat veya tutum gibi kahramanca bir figürden yoksun

\footnotetext{
8 İrfan Başkurt, (2009). “Almanya'da Yaşayan Türk Göçmenlerinin Kimlik Problemleri”, Hasan Ali Yücel Eğitim Fakültesi Dergisi, Sayı 12, s. 84.

${ }^{9}$ Feridun Andaç,(2000). Adalet Ağaoğlu Kitabı/Sen Türkiye'nin En Güzel Kazasısın, İstanbul: Türkiye İş Bankası Kültür Yayınları, s. 145.

${ }^{10}$ Kamuran Eronat, (2010). Adalet Ăgaoğlu, Insan ve Eser, Ankara: Maya Akademi Yayınları, s.141.

${ }^{11}$ http://www.merriam-webster.com/dictionary/antihero, erişim tarihi 21.04.2018
} 
başkişi" ${ }^{12}$ gibi tanımlar yapılmıştır. M. H. Abrams "Modern bir roman ya da oyunda geleneksel kahramanla ya da ciddi karakterli bir eserin başkişisi veya kahramanıyla ilişkilendirdiğimizden oldukça farklı esas kişi.” olarak tanımlar. Anti-kahraman büyüklük, haysiyet, güç ya da kahramanlık ortaya koymak yerine küçük, gösterişsiz, pasif, etkisiz veya sahtekârdır. ${ }^{13}$ Edward Quinn de A Dictionary of Literary and Thematic Terms adlı sözlügünde bu kavrama yer vermiştir. Kavramın tanımını yaparken o da anti-kahramanın "kahraman" (hereoic) kavramının tersini ifade ettiğini söyler. Anti-kahraman korkak, zayıf, beceriksiz ya da sadece şanssız olabilir. ${ }^{14}$

Anti-kahramanların ortaya çıkışı kahraman algısındaki değişimle ilişkilendirilebilir. Bilindiği gibi mitik ve destansı anlatılarda kahramanlar; sıradan insanlardan farklı, üstün, tanrısal bir gücü ya da tanrılar tarafından seçilmişliği ifade eden birtakım özellikleri olan kişiler olarak karşımıza çıkar. $\mathrm{Bu}$ kahramanların daha doğumlarından itibaren bir amacı gerçekleştirmek, içine doğduğu toplumu bir tehlikeden kurtarmak, yeni bir toplum oluşturmak üzere geldikleri belli edilir. Sıradan olmayan bu kahraman sonunda ne olursa olsun hedefini gerçekleştirecektir. Onun başarısız olma ihtimali yoktur.

Zamanla mitik kahraman algısı değişecek, sıradan hatta toplum tarafından kabul görmeyen kişiler kahraman olarak karşımıza çıkacaktır. Abrams, kahraman olmayan başkişi kullanımının 16. yüzyılda picaresqu roman geleneğiyle ortaya çıktığını söyler. ${ }^{15} \mathrm{~J}$. A. Cuddon; çarpıcı, cesur, güçlü, nazik ve becerikli eski moda kahramanların aksine başarısızlığa mahkûmedilmiş anti-kahramanların edebî metinlerdeki ilk kaynaklarının Yunan komedyalarına dayandırılabileceğini söyler. Avrupa'daki en eski örneklerinden biri olarak da Don Kişot'u gösterir. Ona göre ilk modern antikahraman imaj1 ise d'Urfe'nin Astrée'sinde yer alan Hylas'tır. ${ }^{16}$ Edward Quinn anti-kahramanın ilk modern prototipi olarak Dostoyevski'nin Yeraltından Notlar eserinin birinci kişi anlatıcısını gösterir. Hatta yazar romanda, anti-hero terimini kendisi kullanmıştır. ${ }^{17} 19$. yüzyılda anti-

\footnotetext{
${ }^{12} \mathrm{http}: / /$ dictionary.reference.com/browse/antihero , erişim tarihi 11.02.2018

${ }_{13}$ M. H. Abrams, (1999). A Glossary of Literary Terms, Massachusetts: Heinle \& Heinle age, s. 11.

${ }^{14}$ E. Quinn, (2006). E. A Dictionary of Literary and Thematic Terms, New York: Infobase Publishing, s. 28-29.

${ }^{15}$ M. H. Abrams, (1999). A Glossary of Literary Term,. Massachusetts: Heinle \& Heinle, s. 11.

${ }^{16}$ Cuddon J.A, (2013). A Dictionary Of Literary Terms and Literary Theory, Malden: WileyBlackwell, s. 41.

${ }^{17}$ E.Quinn, (2006). E. A Dictionary of Literary and Thematic Terms, New York: Infobase Publishing s. 28-29.
} 
kahramanlar karşımıza yabancılaşmış, sürekli ikilem hâline kişiler olarak çıkar. Emma Bovary, Mr. Pickwick gibi başkişiler bu dönemin antikahramanlarıdır.

İki dünya savaşının yaşandığı 20. yüzyıla gelindiğinde anti-kahraman hayatta bir gayesinin kalmadığını düşünen ciddi "öfkeli genç adam” veya kimlik ve anlam peşinde nafile bir arayış içinde olan "absürt adam" hâlin gelir. ${ }^{18}$ Özellikle İkinci Dünya Savaşı sonrası anti-kahramanların sayısında artış olur. Türkiye'de Selim İleri, Oğuz Atay, Yusuf Atılgan gibi isimlerin eserlerinde anti-kahramanlar bol bol görülür.

Fikrimin İnce Gülü romanının başkişisi Bayram; bencil, ahlaksal kaygıları olmayan, toplumda saygınlık kazanamamış, pek zeki sayılamayacak, bedensel olarak çirkin, kendini saydırmanın yolunu maddede arayan bir anti-kahraman olarak karşımıza çıkar. Bayram'ın 20. yüzyıl antikahramanlarının genelinde görülen anlam arayışı da yoktur. Onun tek amacı saygın olmasını sağlayacak bir otomobil sahibi olmaktır.

\section{Arketipsel Eleştiri}

Arketipsel eleştiri, Analitik Psikoloji ekolünün kurucusu Carl Gustav Jung'un elde ettiği psikoloji verilerini sanatsal ürünlere uygulamasıyla ortaya çıkmış bir inceleme yöntemidir. Psikanalitik incelemelerin başlatıcısı Sigmund Freud'un öğrencisi olan Jung, onun bazı görüşlerini paylaşsa da ondan ayrılan pek çok yönü vardır. Freud, hastalarına uyguladığı teknikleri bir edebiyat inceleme yöntemi olarak kullanmış, incelemenin odak noktasına sanatçıyı yerleştirmiş, eseri sanatçıyı çözümlemek için bir malzeme olarak görmüş̧ür. Ona göre eserin, hastalarının bilinçaltını analiz ederken kullandığ1 rüyalardan çok farkı yoktur. Jung ise psikanalitik incelemenin merkezine eseri yerleştirir. Jung’a göre de eser bilinçdışına ait ögelerle şekillenir. Ancak onun bilinçdışı kavramı Freud'dan biraz farklıdır.

Jung'a göre iki tür bilinçdışı vardır: kişisel ve kolektif (ortak) bilinçdışı. Kişisel bilinçdışı bireyin yaşamından kaynaklanan unsurları kapsar. Kolektif bilinçdışı ise bütün insanlarda/insanlıkta ortaktır. Kişisel bilinçdışından daha derindedir ve insanlığın başlangıcından beri ataların deneyimlerini taşıyarak bir miras gibi yeni nesillere aktarır. Burada insanlığın ilk atalarından hatta hayvan atalardan gelen gizil imgeler bulunur. Bunlar kişisel anılarla ilgisi olmayan ilksel simgelerdir. Jung bu ilk imgeleri

\footnotetext{
${ }^{18}$ Murat Kadirlioğlu, (2014). Savaş Sonrası (1950-1960) İngiliz Tiyatrosunda AntiKahraman, Ankara Üniversitesi Sosyal Bilimler Enstitüsü Batı Dilleri ve Edebiyatları (İngiliz Dili ve Edebiyatı) Anabilim Dalı Yayımlanmamış Doktora Tezi, s.14.
} 
arketip olarak adlandırır. Ancak bunlar mitolojik imge ya da motifler olarak anlaşılmamalıdır. Mitolojik imgeler ya da motifler bilinçli temsillerdir. Arketip, bir motifin bu tür temsilleri oluşturma eğilimidir. ${ }^{19}$ Arketip, tarih boyunca sık sık yinelenen ve yaratıcı fantezinin kendini serbestçe ifade ettiği her yerde beliren bir figürdür. Bu, cin de olabilir, insan varliğg da süreç de olabilir. ${ }^{20}$

Arketipler, uygun durumlarda sınıf, inanç, ırk, coğrafya ya da tarihsel dönem fark etmeksizin insanlarda benzer düşüncelerin, imgelerin, mitolojik motiflerin, duyguların ve düşüncelerin belirmesine neden olur. ${ }^{21}$ Arketipler, yalnızca gelenek, dil ve göçlerle yaygınlaşmaz, her zaman ve her yerde, herhangi bir dış etkenden bağımsız olarak kendiliğinden yeniden ortaya çıkabilir. ${ }^{22}$ Bilinçdışı olan bu imgeler, elle tutulur bir içerikten yoksundur. $\mathrm{Bu}$ sebeple arketiplerin varlığını günlük hayatta açık bir şekilde göremeyiz. Arketipler; rüyalarda, masallarda ve mitik anlatılarda karşımıza çıkarlar. Arketipsel eleştiri; metinlerde persona, anima, animus, gölge, yaşlı bilge, anne, yolculuk gibi arketiplerin izini sürerek bunların kolektif bilinçdışından gelen anlamını çözümlemeye çalışır. Bu arketipler metinlerde biçim ve içerik olarak küçük değişikliklerle karşımıza çıkabilir ancak ifade ettikleri temel anlam aynidir.

Jung, eserin yaratımını da arketiplerle ilişkilendirir. Ona göre eser yaratılırken kullanılan malzeme insanın kişisel yaşamından değil, kolektif bilinçdışından gelir. Yaratıcının rolü, nispeten pasiftir. Eserde, sanatçının müdahalesinden çok, arketiplerin canlandırılması söz konusudur. Bu durum aynı zamanda esere evrensel bir önem de kazandırır. ${ }^{23}$

\section{Aşama/Yolculuk Arketipi}

Üzerinde en çok durulan arketiplerden biri de aşama ya da yolculuk olarak adlandırılan arketiptir. Joseph Campbell bu arketipi "ayrılma, erginlenme ve dönüş" olarak formüle eder. Bir kahraman olağan dünyadan çıkıp doğaüstü tuhaflıklar bölgesine doğru ilerler. Burada masalsı güçlerle karşılaşıllı ve bir zafer kazanılır. Kahraman, bu maceradan benzerleri

${ }^{19}$ Carl Gustav Jung, (2016). Insan ve Sembolleri, çev. Hatice Mukaddes İlgün, İstanbul: Kabalc1 Yayınevi, s. 63.

${ }^{20}$ Carl Gustav Jung, (2006). Analitik Psikoloji, çev. Ender Gürol, İstanbul: Payel Yayınevi, s. 323.

${ }^{21}$ Anthony Stevens, (2014). Jung, çev. Nursu Örge, Ankara: Kültür Kitapçı1lı̆̆ı, s. 76.

${ }^{22}$ Carl Gustav Jung, (2006). Analitik Psikoloji, çev. Ender Gürol, İstanbul: Payel Yayınevi, İstanbul, s. 323, s. 20.

23 Oğuz Cebeci, (2004). Psikanalitik Edebiyat Kuramı, İstanbul: İthaki Yayınları s.328. 
üzerinde üstünlük sağlayan bir güçle geri döner. ${ }^{24} \mathrm{Bu}$ yolculuk, anlatılar hangi kültür ve tarihte yaratılmış olursa olsun karşımıza çok az değişikliklerle çıkar.

Kahramanın yolculuğu aslında bir bireyleşme sürecini ifade eder. $\mathrm{Bu}$ bireyleşme süreci kahramanın bilincinin ve bilinçdışının uyumlu bir şekilde bir araya gelmesiyle gerçekleşecektir. Bireyleşme sürecini edebi metinlerde bir yolculuk şeklinde görürüz. Aşama arketipi kişinin geçirdiği değişimi sembolize eden bir arketiptir. ${ }^{25}$ Yolculuk sonunda kahraman başladığ noktaya döndügünde yola çıkanla aynı kişi değildir. $\mathrm{Bu}$ yolculuk aynı zamanda bir iç yolculuktur. Dış dünyada güçlüklerle mücadele eden kahramanın iç dünyasında da egosuyla yüzleşmesi ve onu aşarak bütünlük haline ulaşması gerekir.

Kahraman çoğu zaman bu yolculuktan değişimini temsil eden bir ödül nesnesi ile döner. $\mathrm{Bu}$ nesne ona daha önce sahip olmadığı güçleri verir. Kahramanın görevini başarıyla tamamladığını gösteren bu nesne aynı zamanda kahramanın kendisinde ya da içinde bulunduğu dünyada bir eksikliği de ortadan kaldıracaktır.

Kahramanın ilk işi ikincil etkilere ait dünya sahnesinden ruhun, güçlüklerin gerçekten yerleşmiş olduğu şu nedensel bölgelere geri çekilmek ve orada güçlükleri halletmek, kendi özelinde onların kökünü kazımak ve bozulmamış, dolaysız deneyimi aşmaktır. Kahraman, yerel ve kişisel tarihsel sınırlamalarla çatışarak onları aşmış, genelgeçerliği olan insani biçimlere ulaşmıştır. Bu noktadan sonra modern bir insan olarak ölen kahraman evrensel bir insan olarak yeniden doğar. $\mathrm{Bu}$ nedenle kahramanın ikinci önemli görevi ve amacı dönüşmüş olarak geri dönmek ve yenilenmiş yaşamdan aldığ 1 dersi öğretmektir. ${ }^{26}$

Yolculuk arketipi daha çok mit, masal, halk hikâyesi gibi türler üzerinde ele alınmıştır. Modern anlatılarda ise çoğu zaman epik nitelik taşıyan eserlerde yolculuk arketipi üzeride durulmuştur. Bu arketipi insan-1 kâmil mertebesine ulaşma sürecinde çekilen çileyle ilişkilendiren çalışmalar da mevcuttur. Bu anlatılardaki kahramanlar ya tanrısal özellikleri olanlar ya da insanlar içerisinde fiziksel ya da ruhani yönleriyle diğerlerinden üstün,

\footnotetext{
${ }^{24}$ Joseph Campell, (2013). Kahramanın Sonsuz Yolculuğu, çev. Hatice Mukaddes İlgün, İstanbul: Kabalc1 Yayınları, s. 42.

${ }^{25}$ Volkan Karagözlü, (2012). "Arketipsel Sembolizm Bağlamında Mihr ü Vefa Mesnevisinin İncelenmesi”, Turkish Studies-International Periodical For The Languages, Literature and Histary of Turkish and Turkic Volume 7/1 Winter 2012, s.1412.

${ }^{26}$ Joseph Campell, (2013). Kahramanın Sonsuz Yolculuğu, çev.Hatice Mukaddes İlgün, İstanbul: Kabalc1 Yayınları, s. 29,31,
} 
idealize edilmiş kahramanlardır. Ancak modern edebiyatta bu alışılmış kahraman kalıplarının dışında insansı zaafları ve kusurları bulunan, sıklıkla toplum tarafından hayal kırıklığına uğratılmış ya da uğratılma yolunda olan, her zaman doğruyu yapma peşinde olmayan, kendisi için doğruyu yapmak isteyen, toplumun yanlış anladığı, her zaman yalnız olan anti-kahramanlar da karşımıza çıkar. ${ }^{27}$

\section{1. Ayrılış / Yola Çıkış}

Kahramanın yola çıkışı "maceraya çağrı" ile başlar. Başlangıçta kendi dünyasında sıradan yaşamına devam eden kahraman, bir habercinin gelmesiyle alışılmış ufkun dışına çıkar. Macerayı başlatan bir hata ya da şans olabilir. Çağrının tipik ortamı karanlık orman, büyük ağaç, çağıldayan kaynak ve kaderin gücünün taşıyıcısının beklenmedik, tasarlanmamış ortaya çıkışıdır. ${ }^{28}$

Romanın başkişisi Bayram'ı kendi dünyasından dışarıya, bilinmeyen mücadele bölgesine çeken olay daha çocukken yaşanır. Bayram, annesi ve babasını kaybetmiş, fakir amcasının yanında yaşayan bir çocuktur. Onun için bütün dünya köyü Ballıhisar'dan ibarettir. Kahvedeki radyo; uçaklardan trenlerden vapurlardan, seçim kampanyalarından bahseder. Ancak Bayram için bunların olup bittiği her yer aydan da uzak ve bilinmezdir. ${ }^{29}$

Çocuk Bayram, ilk klakson sesini köyün girişindeki kuru çeşmenin başında zerdali çekirdeği kırmaya çalışırken duyar. Sesi duyuşundan sonra bir de toz bulutu görür. Bu toz bulutu etrafta ne kadar inek, tavuk, kaz, eşek, ördek varsa sağa sola kaçırtır. Tarlalarda, tüneklerde, bostanlarda, dam altlarında, hendeklerde, duvar artlarında ne kadar adam ve çocuk varsa peşine takarak köyün ortasına dek koşturur. Bayram da amcasının oğlu Remzi ile birlikte toz bulutunun peşine takılır. Toz bulutunun altından mavimtırak bir Ford marka araba çıkar. Bu araç, Demokrat Parti'nin aracıdır. Köy kahvesinde bulunan herkes arabanın etrafını sarar, arabadan çıkan adamın eline sarılır. Kahvedekiler ayağa firlar, yerlerini adama vermek için yarışır. Bu sahne, mitik anlatıların başında yer alan kozmosun kaosa dönüş sahnelerini hatırlatır. Her ne kadar istediği bir hayat olmasa da Bayram belli bir düzende, hiç değişmeyen bir hayatı yaşamaktadır. Zaten bu hayatın

\footnotetext{
${ }^{27}$ Zeynep Ünal, “Üç İstanbul'un Protagonisti Adnan Bir Anti-Kahraman Mı?” ( İlgili kısım Zeynep Ünal'ın çevirisinden alınmıştır.) http://english.learnhub.com/lesson/7614-anti-heroesin-literature) erişim tarihi 11.02.2018

${ }_{28}$ Joseph Campbell , (2013). Kahramanın Sonsuz Yolculuğu, çev.Hatice Mukaddes İlgün, İstanbul: Kabalc1 Yayınları, s. 67.

${ }^{29} \mathrm{Bu}$ çalışmada yapılan alıntılar Adalet Ağaoğlu. (2011). Fikrimin İnce Gülü, İstanbul: Türkiye İş Bankası Kültür Yayınları baskısına aittir.
} 
dışında bildiği bir hayat da yoktur. Dışarıdan/ötekinden gelen bir müdahaleyle birlikte onun kozmosu bozulur. Artık dünyası bildiği, tanıdığı dünya değildir.

Kahramanın yolculuğunun "maceraya çağrı" olarak adlandırılan ilk aşaması kahramanı çağıran ve onun ruhsal ağırlık merkezini toplumun sınırlarından bilinmeyen bir bölgeye çekmiş olan kaderi belirler. ${ }^{30}$ Kahramanın, yeni yaşamını belirlemek üzere birdenbire ortaya çıkan figüre karşı koyması imkansızdır. Romanda Bayram'ın macerasını başlatan, onu maceraya çağıran, tetikleyen haberci bir arabadır.

Bayram'ın saygın biri olmayı arabayla bağdaştırması bu olay sonucu gerçekleşmiştir. Arabanın içinden çıkan sıradan bir insan değil, bir "bey"dir. Bayram; amcası gibi yoksul, dışlanmış, ezilmiş biri olmak istemez. Bir arabanın sahibine bu kadar saygı gösterildiğine şahit olunca kendi kurtarıcısı olarak da bir arabayı görür. Bir motorlu aracı ilk görüşü olan o günden sonra da yirmi beş yıl boyunca böyle bir araca sahip olmanın daha doğrusu arabanın getireceği saygınlığın peşinde koşacaktır.

Kahraman ilk çağrıyı aldıktan sonra yaşadığı dünyadan macera bölgesine geçmek için bir eşiği aşmak zorundadır. Bu eşikte bir eşik muhafızı bulunur. Bu tür muhafızlar kahramanın şu anki alanı ya da yaşam ufkunun sınırlarını belirterek dünyayı dört yönde -ayrıca aşağıda ve yukarıda - sınırlar. Onların ardında karanlık ve bilinmeyen bir tehlike vardır. $^{31}$

Bayram'ın eşiği köy sınırlarıdır, eşik bekçileri ise ona inanmayan, aklına taktığ taksiyle dalga geçen, "deloğlan, İncegül Bayram” diye onunla alay eden köylülerdir. Çoğu zaman bu ilk eşiğin aşılmasında kahramana daha sonraki zamanlarda da yardım edecek bir figür görülür. Ancak Bayram bu yardımdan yoksundur. Onu bir arabaya dolayısıyla da toplumun saydığı bir insan olmaya götürecek yola çıkabilmek için önce bu eşiği aşması gereklidir.

Bayram'ın köyden ilk çıkışı on beş yaşındayken olur. Köyün zengin ailesi Düldüller'in oğlu Sivrihisar'da Shell benzin pompasını kiralamıştır. Bayram'ın amacı burada işe girip araba alabilecek parayı kazanmaktır. Aslında Bayram'ın köyden ilk ayrılışına çıkıştan çok kaçış demek doğrudur. Bir kağnının samanları arasına saklanarak Sivrihisar'a doğru yola çıkar.

\footnotetext{
${ }^{30}$ Joseph Campell, (2013). Kahramanın Sonsuz Yolculuğu, çev. Hatice Mukaddes İlgün, İstanbul: Kabalcı Yayınları, s. 72.

${ }^{31}$ A.g.e. s. 94.
} 
Köyden Sivrihisar'a gidişi Bayram'ın aştığı ilk eşiktir ancak sonuncu değildir. Gittiği her yeni mekânda aşılması gereken daha büyük bir eşik onu bekler. Aşılan her eşiğin arkasında da bilinmeyen yeni bir dünya vardır. $\mathrm{Bu}$ önemli hazine ve tehlike bölgesi çeşitli biçimlerde sunulabilir:Uzak bir ülke, bir orman, yer altında, dağların altında ya da gögün üstünde bir krallık, gizli bir ada, sisli bir dağ tepesi ya da derin bir düş hali; fakat tuhaf biçimde akışkan ve çok biçimli varlıkların, hayal edilemez eziyetlerin, insanüstü görevlerin ve olanaksız zevklerin yeridir. ${ }^{32}$

Büyülü eşikten geçiş bir yeniden doğum alanına geçişi de temsil eder. Kahramanın geçtiği bu yeni dünya bir rahim imgesi olan balinanın karnıdır. $\mathrm{Bu}$ mekân kahramanın yeniden doğmak üzere içe doğru gittiği yerdir. ${ }^{33}$ Bayram için tek bir eşik olmadığı gibi tek bir balina karnı da yoktur. Sivrihisar'dan sonra Eskişehir'e, Ankara'ya en sonunda da Almanya'ya gidecektir. Buralarda arabasına yani saygınlığa ulaşmasının önüne çıkan engellerle mücadele etmesi gerekecektir.

\section{2. Erginlenme}

Eşiğin aşılmasından sonra kahraman, bilinmezliklerle dolu bu yeni dünyada ilerlemeye başlar. Bu aşamada kahramanın aşması gereken zor görevler vardır. Eşiğin ötesinde kahraman bazıları onu şiddetlice tehdit eden (sınavlar), bazısı büyüsel yardım veren (yardımcılar), alışılmadık fakat tuhaf biçimde çekici güçler dünyasında yolculuk eder. Mitolojik çevrimin en alt noktasına gelince büyük bir sıkıntı atlatır ve ödülünü alır. ${ }^{34}$

Küçük yaştan beri ezilmiş, horlanmış olan Bayram'da kendisini saygın yapacak tek yol olarak gördüğü bir araba sahibi olma düşüncesi saplant1 haline dönüşür. Bir "taksi”ye kavuşmadan hiçbir şeye kavuşamayacağını düşünür. Onu bir arabaya ulaştırabilecek her yolu mübah görür. Bunun için en yakınındakilere bile zarar verir, arabasıyla arasına giren her şey onun için bir engeldir ve ortadan kaldırılmalıdır. Masallarda prensin prensese ulaşmak için yok etmesi gereken ejderhalar neyse Bayram için de onu arabasından uzak tutacak her şey odur. Bu yolda yavuklusu Kezban bile onun için bir engel, baştan savulması, atılması gereken bir düşmandır. Onu sever ama yolundan edecek diye yaklaşmasına izin vermez.

"Çekil klz! Git, geldiğin yere. Benden sana hayır yok demedim miydi? Nerden buldun beni sen yine? Nasıl bir yürek ki bu caymiyorsun? Benim de

${ }^{32}$ Age, s. 72

${ }^{33}$ Age, s.107.

${ }^{34}$ Age, s.273. 
başımı bulandırıyorsun... Beni yolumda edecek sendeki bu inat.” (Ağaoğlu , 2006: 103)

“Aman Bayram, at kendini bir an önce Almanya'lara. Yoksa her yan tuzak dolu. Şimdi gidemezsen bir daha gidemezsin. Beklerken beklerken bakmışsın, bu Kezban'ın çakır gözlerine kanıvermişsin!.. İşte o gün temelli boku yedin." (Ağaoğlu , 2006: 181)

Bayram için her şeyin ön şartı bir arabaya sahip olmaktır. Kezban'a "Ben bu taksiye kavuşmasan hiçbir şeye kavuşamam" der. Taksisi olmadan her şey ona haramdır. Bir araba hem istikbal hem şan ve şereftir. Şansız şerefsiz düğün de olmaz. "Dün köyde atlının itibarl ne ise bugün de dört tekerlek bir motorlu üstünde olmanın itibarı odur”. (Ağaoğlu, 2006: 184) Kezban, onu hoş görmeye çalışır. Taksi diye tutturmasının kendisi için olduğunu düşünür. İnsandan korkup sevdasını bir makineye sardırdığına inanır. Küçük görülmüş, ezilmiş, yok sayılmış Bayram gibiler için taksi bir yiğitlik belgesidir. Eskiden ejderha boynu vuranlar gibi o da bir taksiyle yiğitliğini göstermeye çalışır:

"Taksi diye tutturuyorsa yine benim için tutturuyor. Beni rahat ettirmek istiyor. Eskilerde bir adam sevdiğine yiğitlik göstermek için ejderha boynu vururmuş. Dăg devirir baş dikeltir, susuz yerde su bitirirmiş. Bu zamanda Bayram gibilere güç hedef ne? Bu işte. Altına taksi çekmek önüne sinema çekmek. ... Bizim gibilere, Bayram gibilere övünç belgesi, yiğitlik belgesi bunlar oldu artık." (Ağaoğlu , 2006: 289)

Bayram'ın arabaya olan sevdasıyla Kezban'a olan sevdası aklında karışmış durumdadır. "Fikrimin İnce Gülü”" şarkısı ona hem bir kadını hem bir arabayı hatırlatır: Ben bir taksiye mi sevdaliydım? Bu şarkıya mı, bu şarkıyı çağıran sesine mi? Kezban'a mı yoksa? (Ağaoğlu, 2006: 172) soruları aklında dolanır durur. Bu şarkıyı duyduğunda gözünün önünde bir kadından çok köyde gördüğü Ford canlanır.

Bayram'ın araba alabilecek parayı kazanmak için durup dinlenmeden çalışması gerekir. Önce Sivrihisar'da araba lastiği işinde çalışmaya başlar. Polatlı' da minibüsçülük yapar. İki üç ay benzin pompası çalıştırır. Ankara'da gündüzleri Temizel Oto Tamir'de, Rıfat Usta'nın yanında çalışır, geceleri dolmuş şoförlüğü yapar. Bu kadar çok çalışmasına rağmen tam bir araba alacak para biriktirdiği anda hesapları bozulur, yolu çıkmaza girer. Bir keresinde kaynak makinesine yüzünü yaktırır, tedavi içi biriktirdiği bütün parayı harcar. Afyonlu bir iş adamı ona bir benzin pompacısı satmak ister. Amcasının bütün karşı çıkmalarına rağmen köydeki tarlasını satıp burayı alır. Ancak benzin pompacısının önünden geçen yol değişince batar. Belki 
de hedefine yakın olmak amacıyla hepsi de arabayla ilgili olan bu işlerin hiçbirinden istediği sonucu alamaz.

Bayram, bu şekilde çalışarak gerekli parayı biriktiremeyeceğini anlar, Almanya'ya gitmek için sıraya yazılır. Ancak bu sıranın ne zaman geleceği belli değildir. Bu sırada köylüsü İbrahim'le karşılaşır. Onun Almanya'ya gitmek için kooperatifte kalan tek sıraya yazıldığını öğrenir. Bayram, bu kestirme yolları kendisinin nasıl bilmediğine hayıflanır. İbrahim bütün aşamaları tamamlamış, sadece sağlık kontrolü kalmıştır. Bayram, günlerdir Ankara'da belge peşinde koşmaktan perişan olan İbrahim'e yardımcı olmak için hastaneden test sonuçlarını alabileceğini söyler. Kezban'a yedireceği bir simidi düşünecek kadar ince hesaplar yapan Bayram, İbrahim'i köfteciye götürür, ona çok iyi davranır. Bunları yaparken aklında kendi çıkarı vardır. Almanya'ya gitme işinin girdisini çıktısını iyice öğrenmek ister. Ertesi gün sonuçları almaya gittiğinde ise rüşvet vererek İbrahim'in çürük çıkmasına neden olacak ve onun yerine kendisi Almanya'ya gidecektir. Bu olay zaman zaman onun vicdanını rahatsız eder. Ancak kendini haklı çıkaracak bir sebep mutlaka bulur. İbrahim'in amacı Eskişehir'de bir bakkaliye dükkanı açıp çocukları okutacak parayı kazanmaktır. Bayram'a göre bir taksi, traktör alınmayacaksa bu iş Almanya'ya gitmeden de yapılabilir. Bu tür işler araba gibi her y1l model değiştirmez. (Ağaoğlu, 2006: 263)

Almanya'ya gidip çalışmaya başladığında da en kısa yoldan arabasına ulaşmak için kötülük yapmaktan çekinmez. Daha iyi kazanabileceği bir işe geçmesini sağlayan Portekizli bir işçinin işten kovulmasına neden olur. Almanya'da bulunan diğer Türk işçilerle arkadaşlik etmez, kimseye karışmaz. Zaten bencilliği yüzünden kimse tarafından da sevilmez. Kendisini evine çağıran arkadaşı Veli'ye borç ister diye yalan söyler. Memleketlilerinin fabrika kurma teklifini reddeder. Köydeki amcasına para göndermek şöyle dursun onu arayıp sormaz bile. Aklında olan tek şey, gerekli parayı biriktirip arabalı bir Bayram olarak köyüne dönmektir.

Bayram, araba almayı sürekli erteler çünkü en iyisini almak ister. Üç yıl boyunca Almanya'da kaldıktan sonra köylüsü Yaşar'dan öğrendiği amcasının hastalandığı, Kezban'ın da Beyşehirli bir balıkçıyla gittiği haberi üzerine sarı bir Mercedes alır. Yirmi beş yıl süren mücadelesi sonunda önüne çıkan bütün engelleri aşarak hedefine ulaşmıştır.

Genellikle bütün engeller ve devler aşıldığında gelen son macera, başarılı kahraman ruhun Dünyanın Kraliçe Tanrıçasıyla mistik evliliği olarak 
sunulur. ${ }^{35}$ Düşmandan zorla elde edilen hegemonya, canavarın kötü niyetliliğinden kazanılmış özgürlük bir kadın olarak simgelenir. Bu kadın sayısız ejder katletmelerin bakiresi, kıskanç babadan kaçırılmış gelin, melun aşıktan kurtarılmış bakiredir. O bakire kahramanın kendisinin diğer yarısıdır. Eğer kahramanın konumu dünya egemenliğiyse bakire dünyadır ve eğer kahraman savaşçısa bakire de ündür. ${ }^{36}$

Bayram için bu tanrıçanın Mercedes olduğu söylenebilir. Mercedes'i dişil imgelerle ilişkilendirmesi de bunu gösterir. Ona bir masal kahramanın da ismi olan "Balkız" ismini verir. Onu gülüm, gelinim diye sever. Arabasının kaputundaki göçüğe sebep olan Opel sahibinin nikahlısı neyse Bayram için Mercedes'i odur. (Ağaoğlu, 2006:26)

Amma salıverdik kendimizi. Korktuk canırn. Bittik sandık. Oysa Balkız sen, bal gibi Mercedes'lerin en Mercedes'i, en katıksızıymışın da ben boşuna işkillenmişim senden. Ben boşuna, acentadaki satıcının da, senin de günahına girmişim. Bu gidişle sen bana bir ömür boyu yetersin gülüm. Sırtımı yere getirmez, Ballı halkı önünde beni mahcup çıkartmazsın. Gelinim, gülüm, sana baktırırım.Yırtıklarını yamarım. Sen bana vefalı geldikçe böyle, ben sana daha vefal gelirim. Söz. Biz birbirimize denk düşmeseydik sanki İbrahim'in ahı ne ... (Ağaoğlu, 2006:316)

Maceranın başarılmasındaki kolaylığın kahramanın üstün biri, doğuştan kral olmasıyla ilgisi vardır. Birçok peri masalı ve yeniden vücuda bürünen tanrıların görevlerine ilişkin efsanelerde böylesi kolaylıklar görülür. Suradan kahraman sınavdan geçer ama seçilmiş olan kahraman bir engelle karşılaşmaz ve hata yapmaz. ${ }^{37}$ Onların kahramanlıkları elde edilmekten çok önceden belirlenmiştir. Bayram ise bu özelliklere sahip değildir. Kaderini değiştirmek, kendini ispat ederek hor görülmekten kurtulmak üzere çıktığ mücadele alanında bütün engelleyici güçlerle tek başına savaşmak zorunda kalır. Mücadelesinin sonunda kendine göre başarılı olur ve zaferinin göstergesi Balkız'ını alarak kahramanın yolculuğundaki ikinci görevi olan edindiği değişimi ayrıldığı topraklara taşıyıp orayı da kendisi gibi değişime uğratma görevini yerine getirmek üzere dönüş yoluna çıkar.

\footnotetext{
${ }^{35}$ Joseph Campbell, (2013). Kahramanın Sonsuz Yolculuğu, çev. Hatice Mukaddes İlgün, İstanbul: Kabalcı Yayınları, s.125.

${ }^{36}$ Age, s. 373.

37 Joseph Campbell, (2013). Kahramanın Sonsuz Yolculuğu, çev. Hatice Mukaddes İlgün, İstanbul: Kabalcı Yayınları, s.198.
} 


\subsection{Dönüş}

Kahraman, bildiğimiz ülkeden karanlığa doğru yola çıkar, orada macerasını tamamlar ya da basitçe bizle olan bağlarını kaybeder, hapsedilir ya da tehlikeye düşer ve dönüşü o öte bölgeden bir dönüş olarak anlatılır. ${ }^{38}$ Kahramanın son çabası dönüş çabası olacaktır. Macerasını tamamlayabilmek için geri döndüğü dünyanın etkisini atlatabilmelidir.

Dönüş yoluna çıkan Bayram kendisine göre artık eski Bayram değildir. O artık arabalı bir Bayram'dır. Bir Mercedes sahibi olarak kendisini kanıtlamış, saygı görmeyi hak etmiştir. Bundan böyle kimse onu hor görmeyecek, Ballıhisarlılar "deloğlan, ayranı yok içmeye, İncegül Bayram" diye onunla alay ettiklerine, ona inanmadıklarına pişman olacaklardır. Ancak saygın bir kişi, bir bey olarak geri dönmeye dair kurduğu hayaller daha sınırdan geçerken kırılmaya başlar. "Bu girişi yol boyu bambaşka düşlemişti. Önünde ardında yöresinde hiçbir oto, hiçbir kamyon, kamyonet ya da şu tren gibi uzun TIR'lardan bir teki bulunmayacaktı. Sinır kapısından çıkan herkese ve sinır kapısında görevli bütün memurlara karşı öyle, balrengi, gıcır gıcır süzülerek giriverecekti içeri. Kapıda yavaşlayacak, memurların durması için ona saygıyla gösterecekleri yere doğru kayarak ilerleyecekti. Son yüz elli kilometrede hep bunu düşünmüştü.” (Ağaoğlu, 2006: 2)Ancak girişi hiç de düşündüğü gibi olmaz. Sağı solu arabalarla doludur. Üstelik Güldenhause yazılı renkli bir kamyonet önüne geçerek onu iyice kimseye görünemez hale getirir. Kara gözlüklü bir memur "Cakayı bırak da yürü." diye onu azarlar. Memur Nuran Hanım için ezilmesi gereken diğer işçilerden fark1 yoktur, Bayram'ın bal rengi Mercedes'i ona göre sidik rengidir. Mercedes'inin tamponunda oluşan başkalarına göre belli belirsiz, ona göreyse bir felaket olan göçük için attığı feryatları bile önemseyen olmaz.

Kimse imrenerek, kimse hayranlıkla bakmadı ona. Kimse bu arabanın yaşaminda tuttuğu yeri anlamadl. Kimse kutlamadı onu. Kimse arkadaki belli belirsiz de olsa artık varlı̆̆ aklından çıkmayan o küçük göçüğe hayıflanmadl. ... Bir kimse de elini Bayram'ın omzuna koyup "Senin mi bu araba kardeş?" diye sormadı. "Nasıl aldın? Kaça aldın? Kaç yılda? Otomatik mi? Değil mi? Esas döşemesi ne renk? Teybi stereo mu, değil mi? (Ağaoğlu, 2006: 47)

Bayram arabasıyla aynileşmiş durumdadır. Sahip olmadığı saygın kişiliği onunla bütünleşerek hissetmeye çalışır. Artık her şeyi Mercedes'iyle ilgili olarak algılar. Onu fark edenler, güzel bulanlar, taktir edenler Bayram için iyi diğerleriyse kötüdür, mal ve servet düşmanıdır. Zaten onu ve

${ }^{38}$ Age, s.245. 
arabasını takdir eden pek kimse çıkmaz. Takdir edilmeyişini de bir türlü kabullenemez. Kaybolmuş yıldızıyla, arka tampondaki göçüğüyle Balkız da Bayram'1n gözündeki değeri yitirir, sıradan bir araba olur.

Ne memleket yahu kimsenin Mercedes falan taktığı yok... Sen bütün paranı Mercedes'e yatırmışsın. Kimse sana "Aferin adama” demiyor. Lyiydi! Böyle olacağını bilseydim, dört yüz marka o tosbağa Volkswagen'lerin eskisinden alırdım da, dara girmezdim. (Ağaoğlu, 2006: 128, 219)

Arabasıyla dönüş yoluna girmiş olan Bayram'ın mücadele etmesi gerekenler henüz bitmemiştir. Yollarda arabaları yutmak için bekleyen hendekler, koca koca tırlar, kamyonlar, otobüsler, dikkatsiz sürücüler, hatta kendi düşünceleri bile hep mücadele etmek zorunda olduğu canavarlardır. Bayram'ın onları yenerek Ballıhisar'a ulaşması gerekir. Yetişmesi gereken çok şey vardır.

Amcasina görünmek. O ölmeden yetişmek. Remzi Abisine şu saati armağan etmek... İbrahim'i kuzu çevirmeye götürmek, Balkız'ın içinde istediği kadar dolaştırmak onu ve kahvede çenesi düşük herkesi susturmak. Herkese önünde kasket çıkarttırmak. Herkesi, Cemal'i, Adem'i, hepsini kendisine karşı saygll görmek... Biz bir külüstür, bir tozlu Ford'la kahve önüne dayanan fötür şapkalıdan aşağl miyız len? Yoo, isteseler de istemeseler de beni övmek zorundalar artık. Artık "Incegül Bayram”, artık "kediboku”, "deloğlan” bitti. Yok. Tarihe gömüldü. Bu Bayram var işte artık. Kezban'ı Balkız'ın önüne, kendi yanına aldı̆̆ı gibi Almanya'ya dönecek." (Ağaoğlu, 2006: 319)

Bütün dikkatine, çabasına rağmen yol boyunca Mercedes'in gördüğü zarar gümrükteki göçükle kalmaz. Yıldızını kaybeder, ön camı çatlar, susturucusunu deldirir, vapurda askıntı olduğu bir kadın kapısını çarpar, kendisiyle hesaplaşmaya daldığ 1 bir anda farkında olmadan kaputunu tekmeler. En sonunda köye yaklaştığında da bir biçerdöver yüzünden tarlaya yuvarlanır. Aynileştiği arabasına gelen her zararda Bayram'ın kendine olan güveni de azalır. Arabasından geldiğini düşündüğü saygınlığ 1 yok olur. Mercedes'i gibi yeşil hasır şapkası, Franz Lehar yazılı gömleği, kolundaki saati de onu saygın yapacak nesnelerdir. Ancak kaza yapıp tarlaya yuvarlandığında artık bunların bir öneminin kalmadığını hisseder.

Bayram yeniden arabadan çıkıyor. Öne geçip motor kapă̆ını kaldırıyor. Başııı içeriye uzatıyor, fakat az önce yaşadığının ilk habercisi olan yeşil parlak şapkası burada artık can sıkıcı bir yük, bir baş belası. Yere çallyor (Böcek de üç takla atıp firliyor; Bayram'ın sol kaşına konuyor.) Mercedes yıldızı nasıl Balkız'ın onuru idiyse, bu sentetik şapka da öyle 
onuruydu Bayram'ın. Ama şimdi, onur belirleyici bu tür nesnelere yer yok. Bir madalya ancak savaş sonrası avutucu olabilir. Artık yerine getirilmesi olanaksız geçici üstünlükleri hâlâ sürüyormuş gibi göstermeyi, bu aldatmacayı başarabilir. Ya savaş sırasında? Düşmana doğrudan yönelemeyecek her takı bir yük. Bayram,bu sabah Kapıkule'den içeri girerken savaş dönüşü, barış dinginliğinde madalyalarla bezenmiş bir generaldi sanki. Bugünün akşamında tersyüzü ve zorla savaşa itilmiş bir neferdir. (Ağaoğlu, 2006: 313)

Arabasının çalıştığını gören Bayram tekrar umutlanır. Hatta Balkız'ına vefasızlık ettiğini düşünür. Böyle yaralı bereli de olsa köyüne gitmeye karar verir. Köyüne yakın bir çeşme başında arabasını temizlemek, üstünü başını değiştirmek için durur. Burada karşılaştığı çobandan duydukları onun bütün hayallerini yıkacaktır. Köylüler İbrahim'e yaptıklarını öğrenmiştir. Kezban bu yüzden Beyşehirli bir balıkçılla gitmiştir. Köy, tarihi kalıntılar bulununca müzeye dönüşmüştür ve neredeyse boştur. Buraya kadar herkese görünme hevesiyle gelen Bayram artık birilerinin onu görmesinden endişelenir.

Romanın sonunda Bayram, nesneyle kurduğu ayniyet ağlarını da kaybeder. Balkız artık onun için taşınması gereken tonlarca yükten başka bir şey değildir. Aynı günün sabahı Kapıkule'den savaş dönüşü madalyalarla bezenmiş bir generalken akşam tersyüzü zorla savaşa itilmiş bir nefere dönüşür. (Ağaoğlu, 2006:313)

Bayram, arabasını yani saygınlığını kazanmak üzere çıktığı yolculuktan döndügünde kazanmaktan çok kaybetmiştir. Elinde sadece sahip olmak adına bütün hayatını harcadığı ama Bayram'a hayal ettiği hiçbir şeyi veremeyen, dolayısıyla da ona yüklediği bütün anlamları kaybetmiş, neredeyse hurda hâline gelmiş arabası vardır. Kurduğu bütün planlar alt üst olmuş, "bey" olarak yeniden doğacağını düşündüğü merkez yok olmuştur. Onu dönüştürmesini beklerken yok eden merkeze yani Almanya'ya dönmekten başka seçeneği kalmamıştır.

\section{Sonuc}

Jung'un metin merkezli bir kuram olarak ortaya koyduğu arketipsel eleştiride amaç, edebî metinlerde arketipleri tespit ederek anlamlarını yorumlamaktır. Bu arketiplerden biri de kahramanın simgesel olarak bir mekânda çıktığı yolculuğu, gerçekte ise kendi içinde yaşadığı olgunlaşma sürecini ifade eden, Joseph Campbell'in "ayrılma, erginlenme ve dönüş" şeklinde formülleştirdiği yolculuk/aşama arketipidir. Mitik ve epik anlatılarda kaderi kazanmaya doğru çizilmiş kahramanın macerası hemen her zaman zaferle sonuçlansa da modern anlatıların anti-kahramanları için 
aynı şeyi söylemek güçtür. Fikrimin Ince Gülü romanının başkişisi Bayram; yaşadığı aşağılık duygusunu bir arabanın arkasında gizlemeye çalışan, peşinde koştuğu saygınlığ onunla aynileşen, onu arabaya ulaştıracak bütün yolları doğru kabul eden, eşyayla kendisi arasındaki sınırı yitirmiş bir anti-kahraman olarak karşımıza çıar.

Bayram kendisinde dönüşüme sebep olacağına inandığı bir yolculuğa çıkar. Diğer kahramanlar gibi ait olduğu dünyayı (köyü) terk ederek onu dönüştürecek yeni dünyalara (Sivrihisar, Eskişehir, Ankara, Almanya) geçiş yapar. Burada karşısına çıkan engellerle (dolandırıcı Afyonlu işadamı, Kezban, onunla dalga geçen köylüleri, ondan para isteme ihtimali olan herkes, dönüş yolundaki araçlar, dikkatsiz sürücüler, arabasının kıymetini anlamayan gümrükçüler, gurbetçiler vb.) mücadele eder. Sonunda ona saygın bir kimlik verecek ödül nesnesini (otomobil) kazanarak geri döner. Ancak döndüğünde terk ettiği dünyayı bıraktığı gibi bulamaz. Bayram'ın kazandığı ödül nesnesi ne kendisine ne de dünyasına bir yenilik getirmiştir. Yolculuğunun sonunda Bayram, saygın bir kimlik kazanmış olmayı hedeflerken önceden sahip olduklarını da yitirmiş olarak karşımıza çıkar.

\section{Kaynakça}

Abrams, M. H. (1999). A Glossary of Literary Terms, Massachusetts: Heinle \& Heinle.

Adıgüzel, Yusuf (2011). Almanya Türkleri’nde Dil-Din-Kimlik, İstanbul: Şehir Yayınları.

Adler, Alfred (2002). Sosyal Duygunun Gelişiminde Bireysel Psikoloji, çev. Halis Özgü, İstanbul: Hayat Yayınları.

Adler, Alfred (2009). Bireysel Psikoloji, çev. Ali Kılıçlığlu, İstanbul: Say yayınları.

Ağaoğlu, Adalet (2011). Fikrimin İnce Gülü, İstanbul: Türkiye İş Bankası Kültür Yayınları.

Akyıldız, Hülya Bayrak (2014). "Eylemsizlik ve Anti-kahramanların Dönüştürücü Gücü Üzerine”, Humanitas Say1: 4 Güz, Tekirdağ, Sayfa: 1729.

Andaç, Feridun (2000). Adalet Ăgaoğlu Kitabı/ Sen Türkiye'nin En Güzel Kazasısın, İstanbul: Türkiye İş Bankası Kültür Yayınları. 
Başkurt, İrfan (2009). Almanya'da Yaşayan Türk Göçmenlerinin Kimlik Problemleri, Hasan Ali Yücel Eğitim Fakültesi Dergisi Sayı 12 (2009-2), 81-94.

Campbell, Joseph (2013). Kahramanın Sonsuz Yolculuğu, çev. Sabri Gürses, İstanbul: Kabalcı Yayınları.

Cebeci, Oğuz (2004). Psikanalitik Edebiyat Kuramı, İstanbul: İthaki Yayınevi.

Cuddon, J. A. (2013). Dictionary of Literary Terms and Literary Theory, Malden: Wiley-Blackwell.

Durmuş, Gülşah (2015). "Kahramanın Sonsuz Yolculuğu Bağlamında Ferhat İle Şirin Halk Hikayesi”, Sosyal Bilimler Dergisi, Yı1: 2, Sayı: 3, Haziran 2015, s. 128-137.

Eronat, Kamuran (2010). Adalet A ̆gaoğlu, Ankara: İnsan ve Eser, Maya Akademi Yayınları.

Gürses, İbrahim (2007). “Jung'cu Arketip Teorisi Bağlamında Tasavvufi Öykülerin Değerlendirilmesi: Simurg Örneği”, Uludağ Üniversitesi İlahiyat Fakültesi Dergisi, Cilt:16, Sayı:1.

http://dictionary.reference.com/browse/antihero, erişim tarihi 11.02 .2018

http://www.merriam-webster.com/dictionary/antihero, erişim tarihi 22.04.2018

Jung, Carl Gustav (2006). Analitik Psikoloji, çev. Ender Gürol, İstanbul: Payel Yayınları.

Jung, Carl Gustav (2013). Dört Arketip, çev. Zehra Aksu Yılmazer, İstanbul: Metis Yayınları.

Jung, Carl Gustav (2016). İnsan ve Sembolleri, (çev. Hatice Mukaddes İlgün) İstanbul: Kabalcı Yayınları.

Kadirlioğlu, Murat (2014). Savaş Sonrast (1950-1960) İngiliz Tiyatrosunda Anti-Kahraman, Ankara Üniversitesi Sosyal Bilimler Enstitüsü Batı Dilleri ve Edebiyatları ( İngiliz Dili ve Edebiyatı) Anabilim Dalı Yayımlanmamış Doktora Tezi, Ankara.

Karagözlü, Volkan (2012). “Arketipsel Sembolizm Bağlamında Mihr ü Vefa Mesnevisinin İncelenmesi”, Turkish Studies-International Periodical For The Languages, Literature and Histary of Turkish and Turkic Volume 7/1 Winter. 
Kayaokay, İlyas (2014). "Fuzuli'nin Leyla ile Mecnun Mesnevisinin Arketipsel Sembolizm Bağlamında Çözümlenmesi”, Akademik Sosyal Araştırmalar Dergisi, Yıl: 2, Sayı: 7, Aralık 2014, s.337-351.

Keskin, Hakk1 (2011). Göçün 50. Yılında Türklerin Gölgesinde Almanya, Geleceğe Yönelik Uyum Politikası İçin Görüşler, İstanbul: Doğan Kitap.

Narl1, Mehmet (2002). “Araba Sevdaları”, Türkbilig, 2002/4, Sayfa: 19-28.

Narl1, Mehmet, (2009). Roman Ne Anlatır, Ankara: Akçağ Yayınları.

Özkan, Tuba (2010). "Bamsı Beyrek ve Bay Böyrek Anlatılarında Arketipik İmgeler”, Millî Folklor, Y11 22, Sayı 85.

Pearson, Carol S. (2003). İçimizdeki Kahraman, çev. Semra Ayanbaşı İstanbul: Akaşa Yayınları.

Quinn, E. (2006.). A Dictionary of Literary and Thematic Terms, New York: Infobase Publishing.

Stevens, Anthony (2014). Jung, (çev. Nursu Örge) Ankara: Kültür Kitapçılı̆̆1.

Şenderin, Zübeyde (2010). "Yusuf Atılgan'ın Canistan Adlı Romanında Bir Anti-Kahraman: Selim”, Pamukkale Üniversitesi Sosyal Bilimler Enstitüsü Dergisi Sayı 7, Sayfa 135-142

Uçar, Asl1 (2012). Teselliyi Eşyada Aramak: Türkçe Romanda Nesneler, Doktora Tezi, Ankara: İhsan Doğramac1 Bilkent Üniversitesi.

Uğurlu, Seyit Battal (2000). Adalet Ağaoğlu’nun Hayatı, Romanı ve Hikayeleri Üzerine Bir Araştırma, Ankara: Milli Eğitim Bakanlığı Yayınları

Ünal, Zeynep “Üç İstanbul'un Protagonisti Adnan Bir Anti-Kahraman mı?”, https://www.academia.edu/34186753/, erişim tarihi 11.02.2018.

Yavuzer, Nurgül (2011). "Perseus Kahramanlık Mitinin Arketipsel Sembollerle İncelenmesi”, İstanbul Ticaret Üniversitesi Sosyal Bilimler Dergisi Y11:10 Sayı:19 Bahar 2011 s.193-205. 